\title{
Testing local isolates of entomopathogenic microorganisms against Brown Marmorated Stink Bug Halyomorpha halys in Georgia
}

\author{
Medea Burjanadze, ${ }^{*}$ Natalia Kharabadze, and Nona Chkhidze \\ Agricultural University of Georgia, Vasil Gulisashvili Forest Institute, 0159, Tbilisi, Georgia
}

\begin{abstract}
The brown marmorated stink bug, Halyomorpha halys (Hemiptera: Pentatomidae) (BMSB) is an exotic invasive insect which has spread extensively and established in new area of Black sea regions of Georgia. During 2017-2019, infected adults with fungal disease symptoms were found in population of $H$. halys from different regions of Western Georgia. Three isolates of entomopathogenic fungus Beauveria bassiana sensu lato and one of Isaria cf fumosorosea were recovered. Mycoinsecticide Bover-Ge, based on a local strain of B. bassiana-024 (isolated from soil high mountain of Caucasus Range, provide molecular identification in CABI-UK, gave a unique cultural number - IMI \# 501797 and keep in CABI Genetic Recourse Collection) two concentrations $\left(1 \times 10^{7}\right.$ and $1 \times 10^{8}$ conidia/ml $)$ was tested on the adults of $H$. halys in laboratory and its efficiency reached 72.0-90.5\%. Under laboratory conditions, local isolates of nematodes Heterorhabditis bacteriophora and Steinernema borjomiensis were tested on $H$. halys adults. At three increasing concentrations (200, 500 and $1000 \mathrm{IJs} / \mathrm{mL}), H$. bacteriophora caused bug mortality at the rates of 33-47\%. As for Steinernema borjomiensis, the respective values were 13-33\%.
\end{abstract}

The brown marmorated stink bug (BMSB), Halyomorpha halys (Stål) is native for East Asia. It is nowadays distributed throughout the US, Canada, Europe as a severe invasive agricultural pest [1,2]. BMSB is widely polyphagous, it feeds on over 170 host plants, many of them are of agricultural importance, such as fruit, vegetables, row crops, and ornamentals [3,4]. Following its first detection in 2015, H. halys has been spread extensively and established in new areas of Black sea regions becoming a key pest of many crops in Western Georgia [5]. At present BMSB is highly active, forming outbreaks foci in agricultural and urban landscapes and making the phytosanitary situation quite alarming. Georgia is the third hazelnut-producing country worldwide after Turkey and Italy (FAOSTAT 2017). Nowadays, due to the lack of specific natural enemies, population density of this insect is not downregulated.

The aim of our study was to identify pathogens in populations of $H$. halys in Georgia and evaluate their potential for the pest control. During 2017-2019, adults of H.halys were collected from different regions and sites (Samegrelo, Guria, Imereti) of West

* Corresponding author: m.burjanadze@agruni.edu.ge 
Georgia. More than 350 insects were studied. In different H.halys populations, adults developed mycosis symptoms on the body were observed. Three isolates of entomopathogenic fungus Beauveria bassiana sensu lato and one of Isaria cf fumosorosea were identified (Table 1; Figure 1). Adults infected by Beauveria bassiana and by Isaria $\mathrm{cf}$ fumosorosea $0.3 \%$ were observed at 0.9 and $0.3 \%$ prevalence rate, respectively.

Table 1. Sites of collection adults of Halyomorpha halys

\begin{tabular}{|c|c|c|c|c|c|c|}
\hline \multirow[t]{2}{*}{ Isolate names } & \multirow[t]{2}{*}{ Region } & \multirow{2}{*}{$\begin{array}{l}\text { Geographical } \\
\text { location } \\
\text { (lat.N,long.E) }\end{array}$} & \multirow{2}{*}{$\begin{array}{l}\text { Alti } \\
\text { tude }\end{array}$} & \multicolumn{2}{|c|}{ Habitat } & \multirow[t]{2}{*}{ year } \\
\hline & & & & Habitat & $\begin{array}{c}\text { Sub- } \\
\text { habitate }\end{array}$ & \\
\hline $\begin{array}{l}\text { Beauveria bassiana } \\
\text { MB-101 }\end{array}$ & Samegrelo & $\begin{array}{l}42^{\circ} 33^{\prime} 17^{\prime \prime} \\
41^{\circ} 51^{\prime} 24^{\prime \prime}\end{array}$ & 100 & Orchards & Apple & 2017 \\
\hline $\begin{array}{l}\text { Beauveria bassiana } \\
\text { MB-102 }\end{array}$ & Samegrelo & $\begin{array}{l}42^{\circ} 01^{\prime} 58^{\prime \prime} \\
41^{\circ} 56^{\prime} 28^{\prime \prime}\end{array}$ & 73 & Cultivated & $\begin{array}{l}\text { Hazelnut } \\
\mathrm{s}\end{array}$ & 2018 \\
\hline $\begin{array}{l}\text { Beauveria bassiana } \\
\text { MB-103 }\end{array}$ & Guria & $\begin{array}{l}42^{\circ} 33^{\prime} 17^{\prime \prime} \\
41^{\circ} 51^{\prime} 24^{\prime \prime}\end{array}$ & 50 & Cultivated & Hazelnuts & 2018 \\
\hline $\begin{array}{l}\text { Isaria } \mathrm{cf} \\
\text { fumosorosea } \\
\text { MB-110 }\end{array}$ & Guria & $\begin{array}{l}42^{\circ} 05^{\prime} 47^{\prime \prime} \\
42^{\circ} 12^{\prime} 04^{\prime \prime}\end{array}$ & 30 & Cultivated & Hazelnuts & 2018 \\
\hline
\end{tabular}

Morphological characters were obtained for cultures grown on solid potato dextrose agar (PDA) at $23 \pm 2^{\circ} \mathrm{C}$ in darkness for 14 days after inoculation [6-8], including measurements of conidiogenous cells and conidia acquired with a light microscope (Zuzi, S120; magnification of $400 \times$ and $1300 \times$ ).

The fungi were identified using microscopic preparations made directly from mycelia developing on beetles in dead bark. After morphological analysis of monocultures, individual isolates of Beauveria bassiana sensu lato conidia dimensions were between (1.5) $2.0-3.0(4.0) \times(1.5) 2.0-2.5(3.0) \mu \mathrm{m}$. In case of Isaria cf fumosorosea conidia dimensions were between (2.5) 3.0 - 4.0 (4.6) x (0.7) 1.0 - $2.0(2.5) \mu \mathrm{m}$ [9].

In 2019, a mycoinsecticide Bover-Ge (powder) was registered by National food agency of Georgia as a biopesticide. The bioformulation is based on a local Georgian strain of B. bassiana-024 from high mountain soil of Caucasus Range, supported by molecular identification in CABI-UK, gave a unique cultural number - IMI \# 501797 and keep in CABI Genetic Recourse Collection. The product, tested at two concentrations $\left(1 \times 10^{7}\right.$ and $1 \times 10^{8}$ conidia/ml) against stink bug adults under laboratory conditions showed efficacy of $72.0-90.5 \%$ at 12 days post treatment (Figure 2).

Two entomopathogenic nematodes isolated from Georgian ecosystems Heterorhabditis bacteriophora (HRB, GEO)[10] and new species of entomopathogenic nematode, Steinernema borjomiense $n$. sp., was isolated from the body of the host insect, Oryctes nasicornis (Coleoptera: Scarabaeidae), in Georgia, in the territory of BorjomiKharagauli [11] were used to assay their effectiveness against adult $H$. halys. Under laboratory conditions $\left(22^{\circ} \mathrm{C}\right.$ and $\left.80 \% \mathrm{RH}\right)$, the nematodes were used in the following doses: 1:1000, 1:500, 1:200 infective juveniles (IJs)/ml. H. bacteriophora and S. borjomiensis at the concentrations of $1: 1000,1: 500$ and $1: 200$ induced mortality of $46,6 \%-33,3 \%, 33,3 \%$ $32 \%$ and 33,3\%-13,3\%, respectively at 9 days post treatment of adults H.halis (Figure 3). 

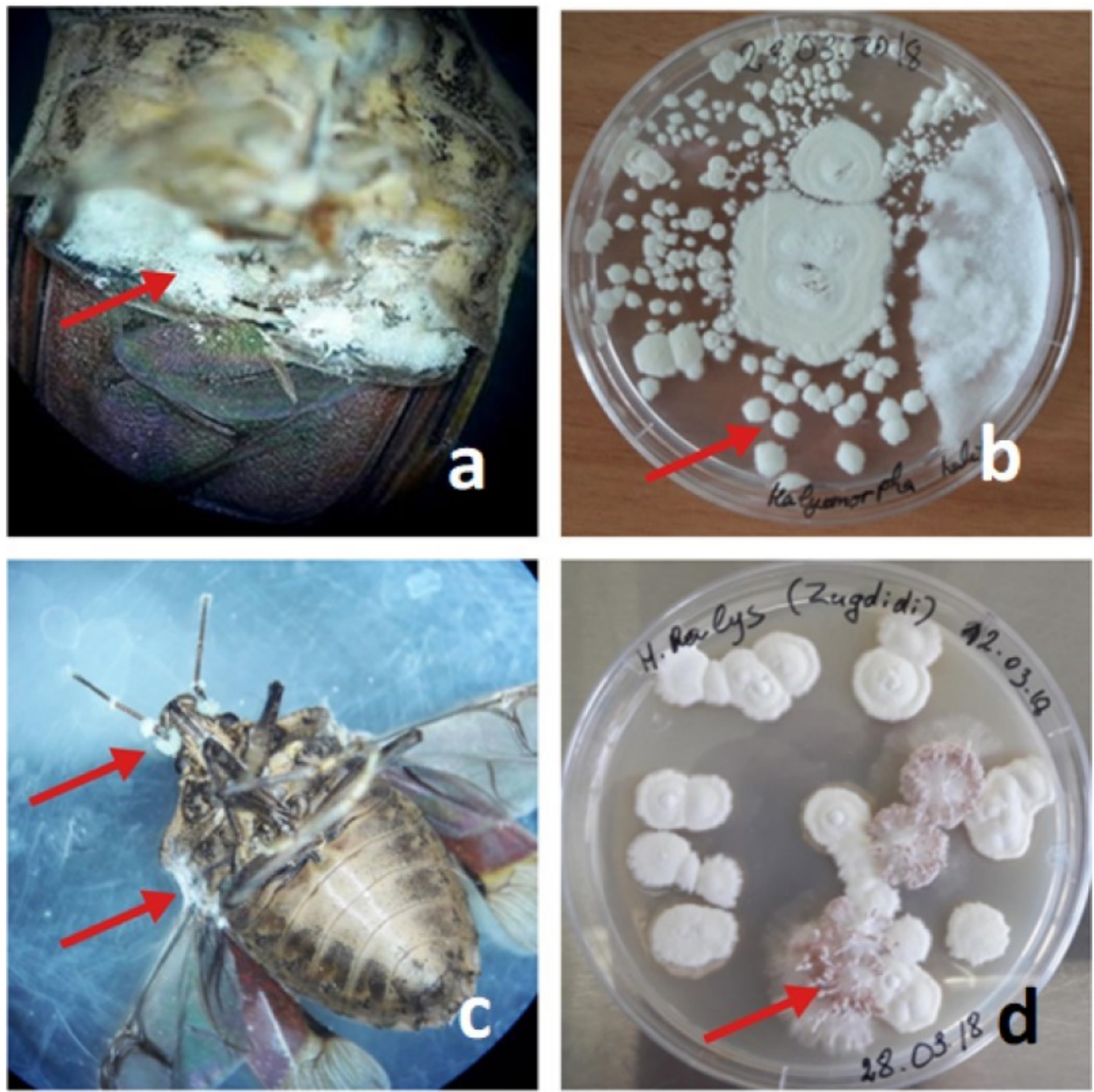

Figure 1. Isolation entomopathogenig fungi from different population of BMSB - H.halys: a- infected adults by Beauveria Bassiana; b - colony develop on the PDA media; $\mathbf{c}$ infected adults by Isaria fumosorosea; $\mathbf{d}$ - colony develop on the PDA media.

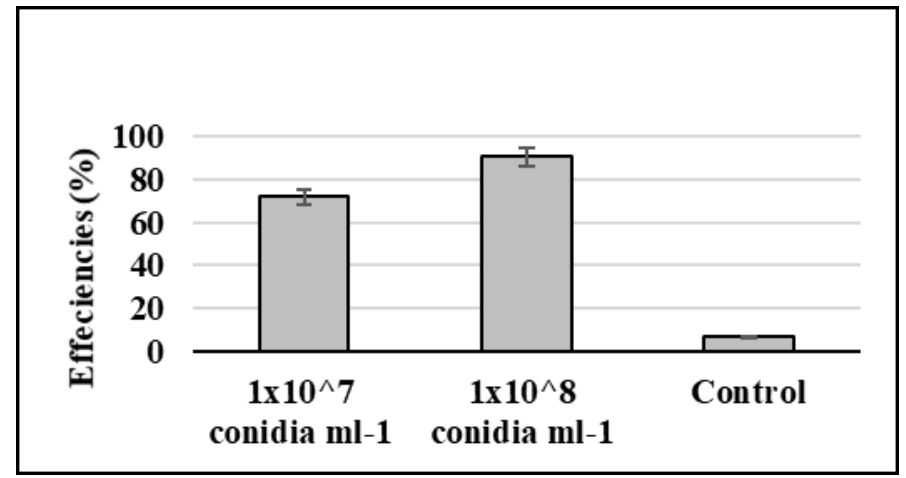

Figure 2. Efficiency of Bover-Ge on the adult Halyomorpha halys under laboratory conditions 


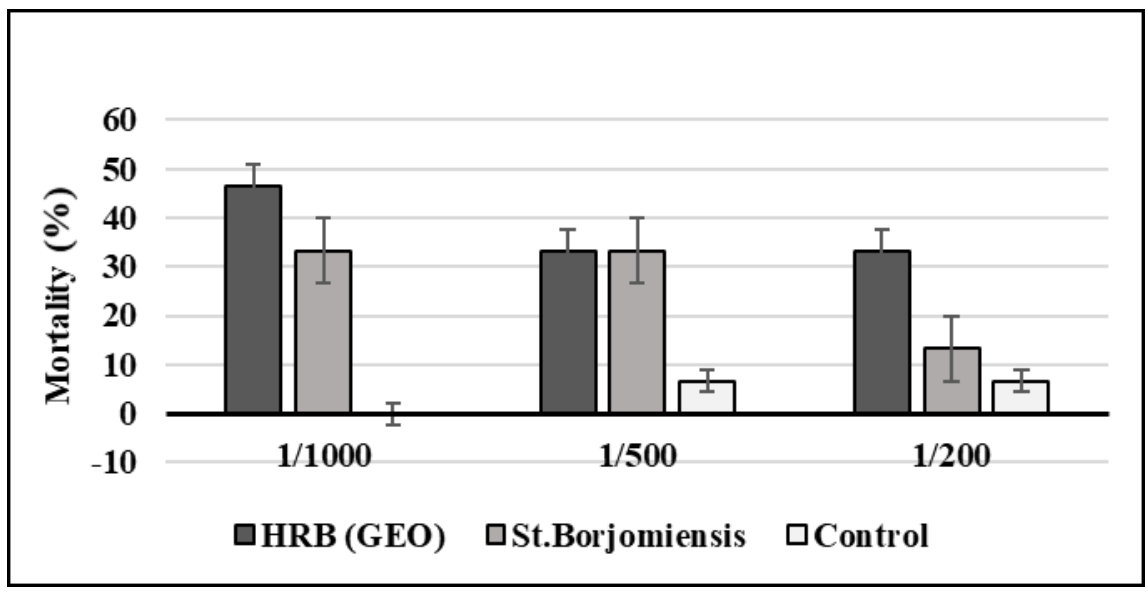

Figure 3. Mortality (\%) of adults of H.halys due to infection with entomopathogenisc nematodes

These results demonstrate high efficiency of entomopathogenic fungi and low potential of the nematodes to control $H$. halys. Further trials are still needed to fully assess the efficacy of these entomopathogens and formulations under different environmental and field conditions. These studies are important both for Georgia and adjacent territories where the pest is also widespread [12].

The research has been supported by NFA-SRNSFG project \# 18-350 “ Develop ecofriendly tools for control Brown marmorated stink bug (BMSB) Halyomorpha halys in Georgia".

\section{References}

1. E.R.Hoebeke, E.M. Carter. Proc Entomol Soc. Wash. 105, (2003)

2. T.C. Leskey, G.C. Hamilton, A.L. Nielsen et al.. Outlooks Pest Man. 23,5, (2012)

3. T.C. Leskey. Bull. Entomol. Res. 105, (2015)

4. N.G. Wiman, V.M. Walton, P.W. Shearer, S.I. Rondon, J.C. Lee. J. Pest Sci. 88, (2014)

5. D.A. Gapon. Entomol. Rev. 96, (2016)

6. A.A. Evlakhova. Entomogenous Fungi. Nauka Press, Russia, (1974)

7. D.W. Roberts, R.A. Humber. Biology of Conidial Fungi. Acad. Press, NY, USA (1981)

8. R.A. Humber. Manual of Techniques in Insect Pathology. 1st ed. Chapter V-1, (1997)

9. G.D.Inglis, J. Enkerli, M.S. Goettel. Manual of Techniques in: Invertebrate Pathology, Chapter VII, (2012)

10. M. A., Lortkipanidze, O.A Gorgadze., N. Gabroshvili., M.Burjanadze, \& M. Kuchava. IOBC/wprs Bull., 113 (2016)

11. O. Gorgadze, E.Fanelli, M. Lortkhipanidze, A. Troccoli, M.Burjanadze, E.Tarasco, F.De LUCA. Nematology, 20 (2018)

12. V.V. Neimorovets. Plant Protection News [Vestnik zashchity rasteniy] 1(95), 11-16 (2018) http://doi.org/10.31993/2308-6459-2018-1(95)-11-16 